\title{
Spontaneous and experimental poisoning by Merremia macrocalyx (Convolvulaceae) in cattle ${ }^{1}$
}

\author{
Luiz B. Brito ${ }^{2}$, Givaldo B. Silva Filho², Hisadora A.S. Chaves², Ana L.O. Nascimento ${ }^{2}$, \\ Thaiza C. Braga ${ }^{2}$, James Pfister ${ }^{3}$, Franklin Riet Correa ${ }^{4}$ (D) and Fábio S. Mendonça ${ }^{5 *}$ (D)
}

\begin{abstract}
Brito L.B., Silva Filho G.B., Chaves H.A.S., Nascimento A.L.O., Braga T.C., Pfister J., Riet Correa F. \& Mendonça F.S. 2019. Spontaneous and experimental poisoning by Merremia macrocalyx (Convolvulaceae) in cattle. Pesquisa Veterinária Brasileira 39(7):447-453. Laboratório de Diagnóstico Animal, Universidade Federal Rural de Pernambuco, Rua Dom Manoel de Medeiros s/n, Dois Irmãos, Recife, PE 52171-900, Brazil. E-mail: mendoncafs@yahoo.com.br

The aim of this work was to describe the epidemiological, clinical and pathological aspects of spontaneous poisoning by Merremia macrocalyx in cattle in the Pernambuco state, northeastern Brazil, and to experimentally replicate the poisoning by this plant. To determine the occurrence of poisonings, 30 farms were visited in six municipalities at the Forest Zone of Pernambuco. The plant was found in nine farms, in which history of plant poisoning in cattle, and occasionally in sheep were also reported. Three outbreaks of spontaneous poisonings in cattle were studied. To replicate the disease experimentally, two steers received a single dose of $60 \mathrm{~g} / \mathrm{kg}$ and two steers received $80 \mathrm{~g} / \mathrm{kg}$ of the fresh leaves of M. macrocalyx in the trough for spontaneous ingestion. Two steers were also used as a control group. The main clinical signs observed in spontaneous cases consisted of restlessness, bloat, polyuria, diarrhea, and death within 48 to 72 hours after the onset of clinical signs. Cattle experimentally poisoned presented similar clinical signs to those observed in spontaneous cases. Gross lesions consisted of dryness and impaction of the rumen, omasum and reticulum contents. Abomasal content was fluid, the mucosa was hyperemic, with swollen folds and multiple ulcers. Similar lesions were observed in duodenum mucosae. Histologically, lesions observed in the abomasum and duodenum mucosa consisted of necrosis, hemorrhage and inflammatory infiltration of neutrophils and lymphocytes. The wide distribution and palatability of this plant, associated with the high sensitivity of the bovine species verified in this experiment, highlight the importance of this plant in spontaneous cases of poisoning in cattle.
\end{abstract}

INDEX TERMS: Spontaneous poisoning, experimental poisoning, Merremia macrocalyx, Convolvulaceae, toxic plants, plant poisoning, tympanism, ruminants, Pernambuco, Brazil, cattle, toxicoses.

\footnotetext{
${ }^{1}$ Received on March 17, 2019.

Accepted for publication on March 23, 2019.

${ }^{2}$ Postgraduate Program in Veterinary Medicine, Universidade Federal Rural de Pernambuco (UFRPE), Rua Dom Manoel de Medeiros s/n, Dois Irmãos, Recife, PE 52171-900, Brazil.

${ }^{3}$ Poisonous Plant Research Laboratory, Agricultural Research Service, United States Department of Agriculture, 1150 E. 1400 N, Logan, UT 84341, USA.

${ }^{4}$ Estación Experimental La Estanzuela, INIA, Ruta 50, Km 11, Colonia, Uruguay.

${ }^{5}$ Laboratório de Diagnóstico Animal, Universidade Federal Rural de Pernambuco (UFRPE), Rua Dom Manoel de Medeiros s/n, Dois Irmãos, Recife, PE 52171-900. *Corresponding author: mendoncafs@yahoo.com.br
}

RESUMO.- [Intoxicação espontânea e experimental por Merremia macrocalyx (Convolvulaceae) em bovinos na Zona da Mata de Pernambuco.] 0 objetivo deste trabalho é descrever os aspectos epidemiológicos, clínicos e patológicos da intoxicação espontânea por Merremia macrocalyx em bovinos de Pernambuco, nordeste do Brasil e reproduzir experimentalmente a intoxicação por esta planta. Para determinar a ocorrência das intoxicações, foram visitadas 30 propriedades em seis municípios na Zona da Mata de Pernambuco. A planta foi encontrada em nove fazendas 
onde também haviam históricos de intoxicações em bovinos e ocasionalmente em ovinos. Três surtos de intoxicações espontâneas em bovinos foram estudados e para reproduzir experimentalmente a doença, dois novilhos receberam doses únicas de $60 \mathrm{~g} / \mathrm{kg}$ e dois novilhos receberam $80 \mathrm{~g} / \mathrm{kg}$ de folhas frescas de M. Macrocalyx para consumo espontâneo no cocho. Dois novilhos foram utilizados como grupo controle. Os principais sinais clínicos observados na intoxicação espontânea consistiram em agitação, timpanismo, poliúria, diarreia e morte dentro de 48 a 72 horas após a observação dos primeiros sinais clínicos. Os bovinos intoxicados experimentalmente apresentaram sinais clínicos semelhantes aos observados nos casos espontâneos. À necropsia as lesões consistiam em compactação e ressecamento dos conteúdos do rúmen, omaso e retículo. O conteúdo do abomaso estava fluido, notava-se hiperemia das mucosas, as pregas estavam edemaciadas e continham múltiplas úlceras. Lesões semelhantes também foram observadas na mucosa do duodeno. Histologicamente, as lesões observadas na mucosa do abomaso e do duodeno consistiam em necrose, hemorragia e infiltrado inflamatório neutrofílico e linfocítico. A ampla distribuição de Merremia macrocalyx na região estudada e a boa palatabilidade associada à alta sensibilidade da espécie bovina verificada neste experimento, reforça a importância desta planta em casos espontâneos de intoxicação em bovinos.

TERMOS DE INDEXAÇÃO: Intoxicação espontânea, intoxicação experimental, Merremia macrocalyx, Convolvulaceae, bovinos, Zona da Mata, Pernambuco, plantas tóxicas, intoxicação por plantas, timpanismo, ruminantes, toxicoses.

\section{INTRODUCTION}

Merremia genus encompasses a range of 80 species occurring throughout tropical and subtropical regions (Austin 1982). In Brazil 14 of these species can be found in different environments and locations such as forest borders, countrysides and wastelands (Austin 1982, Simão-Bianchini et al. 2016). Merremia macrocalyx belongs to the Convolvulaceae family, it is a herbaceous climbing plant capable of flowering and growing fruits all year round, mainly in the summer, and can be found in the Americas, extending from the United States to Argentina (O'Donell 1941). Considered an invasive plant (Lorenzi 1982, Kissmann \& Groth 1992, Lorenzi \& Souza 1999), M. macrocalyx has already been found in all Brazilian states (Simão-Bianchini et al. 2016, Ferreira \& Miotto 2013).

Although several species of the Convolvulaceae family are nontoxic and important fodder plants widely used for animal feeding (Cook et al. 2013), many toxic plants belonging to this family, especially those in the Ipomoea genus, have been reported causing disease and significant economic losses to livestock production in the Brazilian semiarid region (Mendonça et al. 2011, 2012, Oliveira et al. 2011, Tokarnia et al. 2012, Lima et al. 2013, Oliveira et al. 2013). There are no reports of poisoning by Merremia species in ruminants in Brazil. However, some species are considered toxic in the United States, Oceania, India and Trinidad and Tobago, such as Merremia tuberosa (Ghosh \& Ghosh 2010), M. peltata (Williams 2012) and M. dissecata (Williams \& Williams 1969, Mansur 2001). Merremia tuberosa has hallucinogenic effects in humans, $M$. dissecata is toxic to ruminants due to its alkaloids and glycosides content, and M. peltata has been reported as toxic to fish (Williams \& Williams 1969, Mansur 2001, Ghosh \& Ghosh 2010, Williams 2012).
The aim of the this study was to describe the epidemiological, clinical and pathological aspects of spontaneous poisoning by Merremia macrocalyx in cattle in the Forest Zone of Pernambuco and replicate experimentally the toxicity of this plant in cattle.

\section{MATERIALS AND METHODS}

The epidemiological study was carried out in the Forest Zone of Pernambuco, northeastern Brazil, in the municipalities of Condado, Camutanga, Itaquitinga, Nazaré da Mata, Paudalho and Vicência. Five farms from each municipality were visited in order to investigate the occurrence of spontaneous poisonings by Merremia macrocalyx.

All information concerning distribution, period of occurrence and clinical signs caused by $M$. macrocalyx consumption in cattle were obtained through a questionnaire based on Silva et al. (2006). Subsequently, pasture areas were surveyed to verify the presence of M. macrocalyx and the farms that presented areas containing the plant were monitored for 24 months.

Merremia macrocalyx leaves were collected in Condado and sent to the Poisonous Plant Laboratory, Agricultural Research Service, at the United States Department of Agriculture, Logan/UT, USA for bromatological analysis. For botanical identification, samples were sent to the "Instituto Agronômico de Pernambuco" (IPA). In addition, M. macrocalyx samples collected in Condado and Vicência were tested for the presence of hydrocyanic acid (Tokarnia et al. 2000) and nitrates (Riet-Alvariza 1993). Colorimetric method for nitrate percentage determination was also applied (Embrapa 1997).

In order to carry out the experiment with cattle, the precepts related to animal welfare and ethics were followed, as recommended by the National Council for the Control of Animal Experimentation (CONCEA) and the Ethics Committee on the Use of Animals of the Federal Rural University of Pernambuco (CEUA-UFRPE).

For the experimental poisoning, six crossbred Girolando steers, with age ranging from 12 to 24 months were used. The animals were clinically healthy and weighing between 106 and $195 \mathrm{~kg}$. Thirty days before the beginning of the experiments, cattle received antiparasitic medication and were kept in a shared facility, aiming adaptation and previous clinical observation. During the adaptation period, every day, early in the morning, steers received commercial ration, mineral salt, Napier grass (Pennisetum purpureum) minced in the trough and water ad libitum. After that, animals were kept in paddocks and then taken back to the shared facility at dusk. Prior to the beginning of the experimental trial, cattle were fasted for 12 hours and then distributed into three groups: Group I (control group) was composed by two steers under the same management conditions as the others, however these animals did not consume Merremia macrocalyx. Group II, consisting of two cattle that received fresh leaves of M. macrocalyx in the trough at a single dose of $60 \mathrm{~g} / \mathrm{kg}$, and Group III, composed by two cattle that received fresh leaves of M. macrocalyx in the trough at a single dose of $80 \mathrm{~g} / \mathrm{kg}$.

The animals were clinically examined throughout the experiment period, twice daily. Clinical exams were performed according to Dirksen et al. (1993); hemogram, urinalysis, ruminal fluid analysis (Kaneko et al. 2008) and a test to verify diphenylamine content were also performed. Blood collection was carried out on the first, third and fifth day of the experiment, and a diphenylamine test was performed after the first clinical signs were detected. For physical and chemical evaluation of ruminal fluid, the $\mathrm{pH}$ of samples was checked immediately using $\mathrm{pH}$ indicator strips. Afterwards, color, odor, appearance, flotation-sedimentation, methylene blue reduction and protozoan activity were evaluated (Dirksen 1993). Three evaluations of ruminal fluid were performed. The first evaluation 
was performed prior to the administration of Merremia macrocalyx leaves, second evaluation 24 hours after administration, and the third was performed on the 8th day of experiment on those that survived the poisoning.

Cattle that died were submitted for necropsy, and samples from organs of the abdominal and thoracic cavity, as well as the encephalon were collected, fixed in $10 \%$ formalin, embedded in paraffin, cut into sections ranging from $5-6 \mu \mathrm{m}$ and stained by hematoxylin-eosin (HE) for histological examination. The experimental design is shown in Table 1.

\section{RESULTS}

\section{Spontaneous poisoning by Merremia macrocalyx}

Considering the applied questionnaire, poisoning episodes occurred in farms which shared similar features among each other, such as areas of poorly managed pastures of up to
10 hectares. Outbreaks occurred in periods of low rainfall from August to March. In Condado, Merremia macrocalyx (Fig.1) was five times mentioned as responsible for the deaths of 35 cattle and two poisoning outbreaks were followed. No outbreak was reported in Camutanga and Itaquitinga and in visited sites the plant was not found. In Nazaré da Mata, the plant was mentioned twice as responsible for the death of 27 sheep and three cattle. In Vicência a poisoning outbreak was observed, and in Paudalho it was mentioned twice. In these places $M$. macrocalyx was found in pasture areas and on the banks of the side roads.

Poisoning outbreaks in Condado occurred in November 2013 and February 2014. The first cases were identified during the removal of a batch of five cattle grazing in an area invaded by Merremia macrocalyx. Three out of the five animals consuming the plant presented clinical signs that consisted of restlessness,

Table 1. Experimental poisoning by Merremia macrocalyx in cattle, general data

\begin{tabular}{|c|c|c|c|c|c|c|c|c|}
\hline \multicolumn{3}{|c|}{ Cattle } & \multirow{2}{*}{$\begin{array}{l}\text { Daily dose } \\
\text { (g/Kg) }\end{array}$} & \multirow{2}{*}{$\begin{array}{l}\text { Daily dose } \\
\text { consumed } \\
(\mathrm{Kg})\end{array}$} & \multirow{2}{*}{$\begin{array}{c}\text { Clinical signs } \\
\text { onset }\end{array}$} & \multirow{2}{*}{$\begin{array}{l}\text { Clinical signs } \\
\text { intensity* }\end{array}$} & \multirow[b]{2}{*}{ Evolution } & \multirow{2}{*}{$\begin{array}{l}\text { Outcome } \\
\text { (days) }\end{array}$} \\
\hline Group & Number & Weight (Kg) & & & & & & \\
\hline \multirow[t]{2}{*}{ GI } & 1 & 165 & Control & - & Absent & Absent & - & - \\
\hline & 2 & 178 & Control & - & Absent & Absent & - & - \\
\hline \multirow[t]{2}{*}{ GIII } & 3 & 180 & 60 & 10.8 & $9 \mathrm{~h}$ & +++ & Recovered & 7 \\
\hline & 4 & 195 & 60 & 11.7 & $8 \mathrm{~h}$ & ++ & Recovered & 8 \\
\hline \multirow[t]{2}{*}{ GIII } & 5 & 106 & 80 & 8.48 & $12 \mathrm{~h}$ & +++ & Died & 3 \\
\hline & 6 & 175 & 80 & 14 & $14 \mathrm{~h}$ & +++ & Died & 2 \\
\hline
\end{tabular}

*+ Mild, ++ moderate, +++ severe.
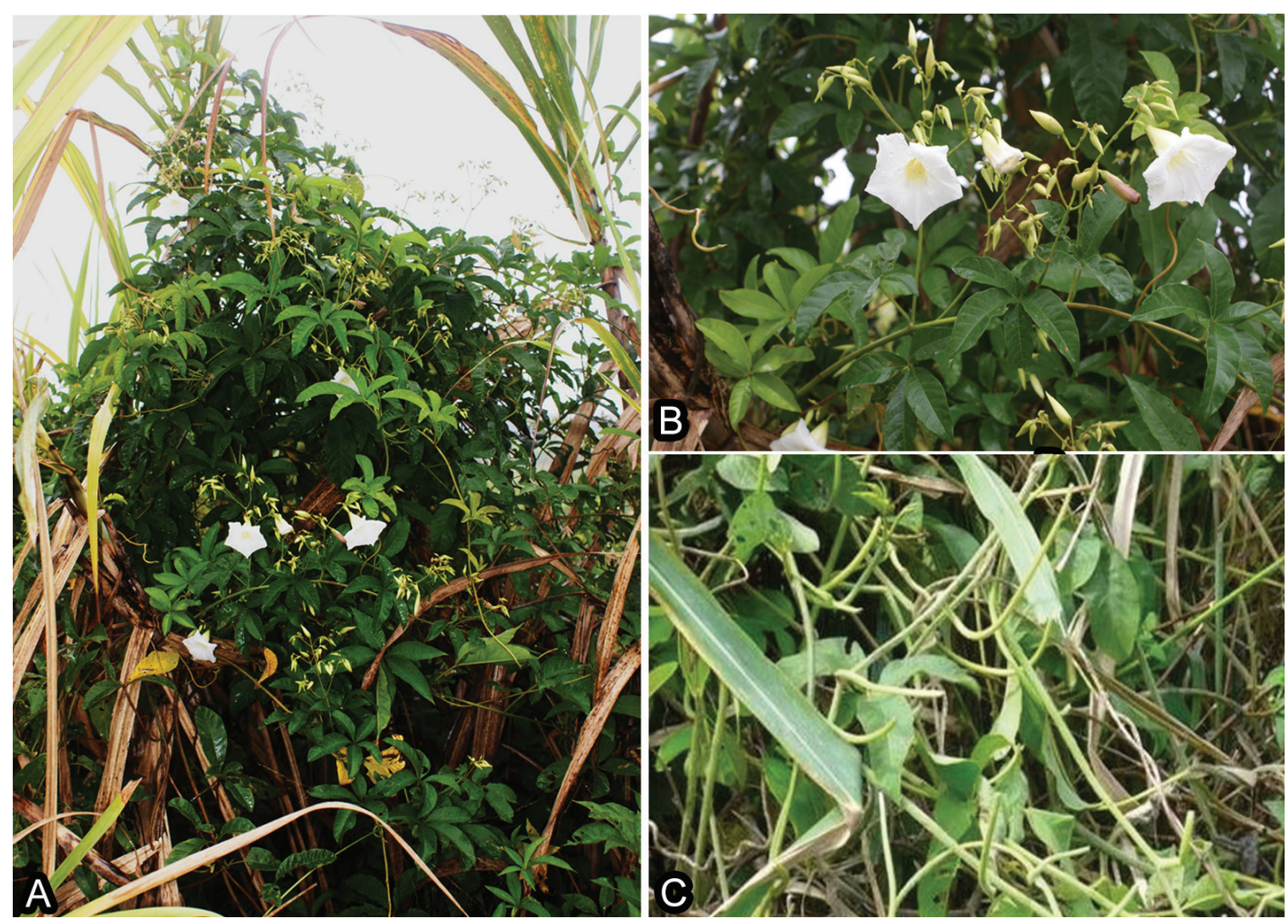

Fig.1. (A) Merremia macrocalyx in cattle grazing area. The plant is observed covering other shrubs, Condado, Pernambuco. (B) Leaves and flowers. (C) Merremia macrocalyx showing evidence of cattle consumption. 
tympanism, ruminal atony, regurgitation of ruminal fluid, polyuria, diarrhea and death 48 to 72 hours after the onset of clinical signs (Fig.2A). In the referred farm, two cattle died, one of which was necropsied. The third one recovered completely within 15 days after ruminal transfaunation. In this farm, deaths in cattle in the previous years with a similar clinical condition were reported, usually including tympanism. In the second outbreak, out of a total of 19 cattle, five showed mild to moderate clinical signs, mainly tympanism and on that occasion one of the animals died and was necropsied.

The third outbreak was observed in Vicência in December 2015. Out of a total of 16 cattle, two presented tympanism, prolonged recumbency, ruminal atony and death in less than 24 hours. The pastures of the three properties were composed of Brachiaria decumbens and in all of them Merremia macrocalyx specimens were observed with signs of being consumed by cattle.
Necropsy findings in two spontaneously poisoned cattle were similar and consisted of tympanism (Fig.2B), blood vessels congestion and petechiae in the rumen serosa. Rumen, omasum and reticulum contents were dry and compacted and abomasum content was liquid (Fig.2C). Abomasal mucosa was hyperemic, with swollen folds and contained multiple ulcers with a maximum of $0.5 \mathrm{~cm}$ in diameter. Cattle had epicardial petechiae and lung consolidation areas and edema in the pulmonary caudal lobes. Histologically, the main lesions consisted of acantholysis, ballooning degeneration of rumen and reticulum keratinocytes, sometimes with the formation of pustules and inflammatory infiltration of polymorphonuclear cells and lymphocytes in the epithelium and the submucosa had marked edema (Fig.2D-F). The abomasum mucosa showed multifocal areas of necrotic epithelium, severe neutrophilic and lymphocytic inflammatory infiltrate; edema, congestion and hemorrhage in the submucosa were also noted. Similar

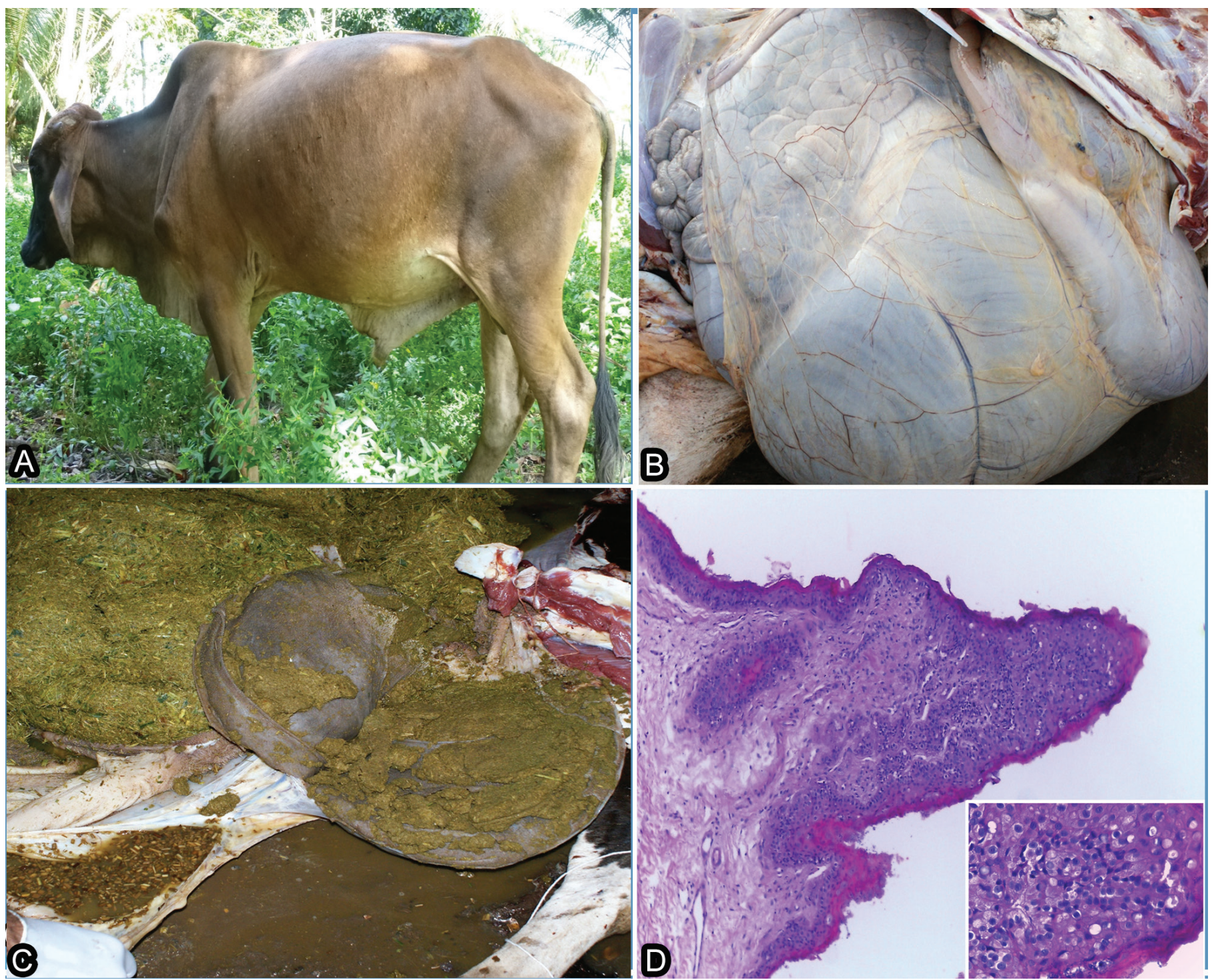

Fig.2. (A) Spontaneously poisoned cattle with severe tympanism. (B) Rumen, reticulum and abomasum show enlargement due to gas accumulation. (C) Dry and impacted rumen and reticulum contents and excessively liquid abomasum content. (D) Rumen mucosa presenting keratinocytes and epithelial necrosis with ballooning degeneration, lymphocytic and neutrophilic inflammatory infiltrate containing bacteria and abscesses. HE, obj.10x. 
lesions, characterized by necrosis and inflammation of the lining epithelium, edema and hemorrhage of the submucosa were also present in the duodenum.

Bromatological analysis of Merremia macrocalyx leaves demonstrated crude protein (29\%), digestibility (89\%) and neutral detergent fiber (27\%). Picro-sodium paper test had a negative reaction, diphenylamine test had a weak blue reaction for nitrates and samples of $M$. macrocalyx collected from Condado and Vicência indicated $0.3 \%$ nitrate concentrations in dry matter.

\section{Experimental poisoning by Merremia macrocalyx in cattle}

Animals that ingested Merremia macrocalyx developed clinical signs within 8 to 14 hours after total consumption and the clinical outcome of the disease lasted from 2 up to 8 days (Table 1 ).
Poisoning clinical signs varied in severity degree yet all animals presented apathy, anorexia, restlessness, irritability, ocular discharges, sialorrhea, dehydration, polyuria and diarrhea. In addition to these clinical signs, individuals that consumed $60 \mathrm{~g} / \mathrm{kg}$ of Merremia macrocalyx leaves presented ruminal motility reduction, mild to moderate tympanism, and fully recovered within 7-8 days. Those in the $80 \mathrm{~g} / \mathrm{kg}$ daily dose presented ruminal motility reduction followed by atony, tympanism, dyspnea, orthopneic posture, muscle tremors, weakness, sternal recumbency and death within 2 or 3 days (Fig.3A). There was a decrease in methylene blue reduction activity and ruminal fluid $\mathrm{pH}$ was alkaline in all cattle, reaching values between 7.5-8.0. Density and motility of protozoa declined progressively only in the most severe cases of intoxication; the percentage of mortality ranged from $60 \%$ to $80 \%$. No significant changes were observed
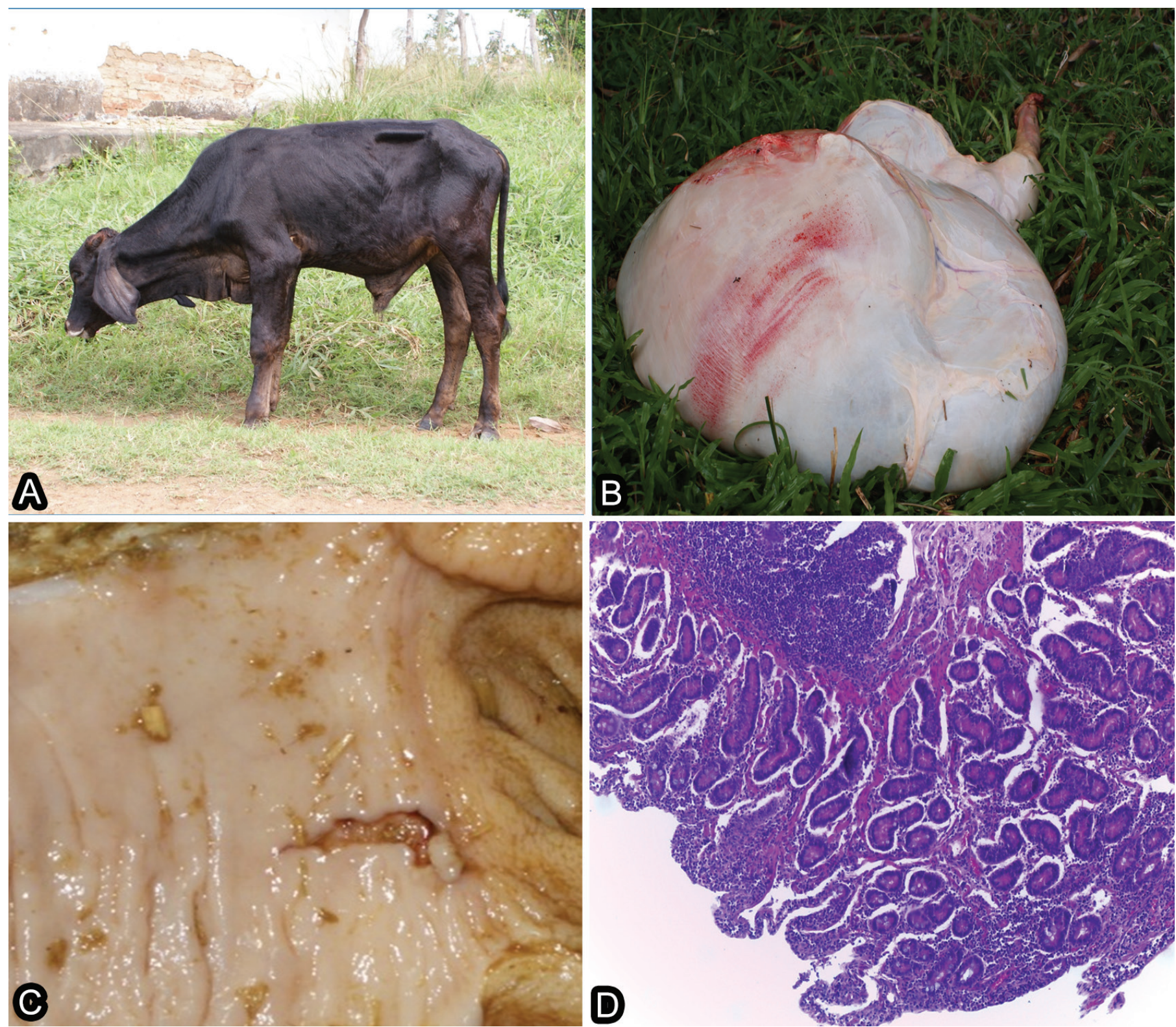

Fig.3. (A) Experimentally poisoned cattle presenting apathy and orthopneic posture due to digestive system lesions. (B) Multifocal areas of hemorrhage are observed in the rumen serosa. (C) Duodenum mucosae presenting erosive lesions. (D) Epithelial necrosis, severe neutrophilic and lymphocytic inflammatory infiltrate of the duodenal mucosae. HE, obj.10x. 
in experimentally poisoned cattle erythrograms. However, there was discreet leukocytosis due to neutrophilia and lymphocytosis. There were no significant changes in the biochemical parameters analyzed.

The group fed with $80 \mathrm{~g} / \mathrm{kg}$ Merremia macrocalyx leaves presented similar lesions to those spontaneously poisoned; these lesions consisted of rumen and reticulum distention with dry contents and petechial hemorrhages in rumen serosa (Fig.3B). Abomasum contents were liquid, there was edema of folds and ulcers with petechial hemorrhages in the mucosa; ulcers were also observed in duodenal mucosa (Fig.3C). Histological findings consisted of rumen and reticulum epithelial necrosis with neutrophils and lymphocytes inflammatory infiltrate, in addition to edema and hemorrhage. Intestinal villi epithelial necrosis with lymphocytic and polymorphonuclear cells inflammatory infiltrate and congestion of the submucosa vessels were also observed in the small intestine, mainly in the duodenum (Fig.3D-F).

\section{DISCUSSION}

Considering the outbreaks of Merremia macrocalyx poisoning and its wide distribution in the Forest Zone of Pernambuco, we can say that this is a toxic plant species of interest for livestock that causes acute tympanism. Currently, due to fodder scarcity, ranchers kept cattle confined or tied by ropes in $M$. macrocalyx higher concentrations areas for the cattle to consume it as source of fodder in drought periods when this plant is found abundantly and remains green for long periods of time. Therefore, main factors favoring cattle poisoning were food shortages, good plant palatability and its presence in poorly managed pasture areas.

Farmers' reports suggest that sheep are also poisoned spontaneously, however, in this species, acute bloat outbreaks have not been identified and need to be investigated. In addition, due to the Merremia macrocalyx occurrence throughout the Brazilian national territory (Simão-Bianchini et al. 2016, Ferreira \& Miotto 2013), veterinarians from other states should be vigilant and should include $M$. macrocalyx poisoning in the differential diagnosis when outbreaks of tympanism are observed in cattle.

Poisoning in cattle had subacute to acute clinical progression, with gas bloating representing the most characteristic clinical sign of the disease; main lesions consisted of necrosis and inflammation of the mucosa of the rumen, reticulum, abomasum and duodenum. The most likely hypothesis for this poisoning pathogenesis is related to the plant toxins action that may cause disturbances in the nerve pathways involved in eructation reflex, since rumen and reticulum mucosa (which contain mechanoreceptors and voltage receptors that discriminate gas, foam and liquid) injuries may disrupt normal reflex which is essential for rumen gas removal (Forbes 1986, Allen \& Mertens 1988, Allen 1996, Radostitis et al. 2002, Andrews et al. 2008).

Merremia macrocalyx toxins responsible for the lesions in the digestive tract of cattle are unknown. However, alkaloids, phenolic compounds and glycolipids are the biologically active constituents most commonly found in various species of Convolvulaceae extracts (Meira et al. 2012). In a previous study with leaves and roots of $M$. macrocalyx, saponins, quinones, steroidal triterpenes, polyphenols and tannins were detected (Bakasso et al. 2008). In other Merremia species, such as $M$. tuberosa, M. peltata, $M$. dissecta and M. guerichii toxic alkaloids were also found (Nahrstedt et al. 1989, JenettSiems et al. 2005, Austin 2007). In another study, 18 distinct types of pyrrolizidine alkaloids were identified in different Merremia species (Jenett-Siems et al. 2005). For this reason, the content of alkaloids in M. macrocalyx leaves should be investigated, since it is known that these nitrogen compounds have as main function to avoid herbivory and, therefore, may be related to the pathogenesis of such intoxication in cattle (Perez et al. 2015).

In Brazil, despite numerous toxic plants of economic importance, there are few with action on the digestive system of cattle (Tokarnia et al. 2012). There is only one species of plant, Trifolium pratense, which causes acute tympanism in cattle in southern Brazil. In these cases, however, tympanism is foamy and occurs due to excessive fermentation of soluble carbohydrates and proteins of high ruminal degradability in plants (Gava 1990, Dalto et al. 2009). The most important species that affect the digestive system are Baccharis coridifolia in the South and Stryphnodendron coriaceum in the Northeast of Brazil (Rissi et al. 2005, Mello et al. 2010). The clinical-pathological signs induced by these plants in cattle are similar to that of $M$. macrocalyx poisoning and include lesions characterized by necrosis and inflammation of the digestive system; without significant alterations in other organs. There is no treatment for $M$. macrocalyx poisoning in cattle, but in spontaneous cases, clinical improvement was observed after oro-ruminal probe and support therapy to correct hydroelectrolytic disorders.

\section{CONCLUSION}

Merremia macrocalyx is a relevant toxic plant for ruminants that causes tympanism and lesions in the digestive system of cattle in the Forest Zone of Pernambuco state, Brazil.

Acknowledgments. To the FACEPE (Process APQ-0202- 5.05/17), CAPES (Finance Code 001) and CNPq (Process 304804/2018-5) for granting the necessary financial support for the development of this study.

Ethics committee.- The experiment was approved by the animal ethics committee of UFRPE (Authorization number 100/2015).

Conflict of interest statement.- The authors have no competing interests.

\section{REFERENCES}

Allen M.S. 1996. Physical constraints on voluntary intake of forage by ruminants. J. Anim. Sci. 74(12):3063-3075. <http://dx.doi.org/10.2527/1996.74123063x> <PMid:8994921>

Allen M.S. \& Mertens D.R. 1988. Evaluating constraints on fiber digestion by rumen microbes. J. Nutr. 118(2):261-270. <http://dx.doi.org/10.1093/ jn/118.2.261 > <Mid:2828582>

Andrews A.H., Blowey R.W., Boyd H. \& Eddy R.G. 2008. Medicina Bovina: doenças e criação de bovinos. $2^{\mathrm{a}}$ ed. Roca, São Paulo. 1080p.

Austin D.F. 1982. Convolvulaceae, p.15-226. In: Febres Z.L. \& Steyermark J.A. (Eds), Flora da Venezuela. Vol.8. Fundación Educación Ambiental, Caracas.

Austin D.F. 2007. Merremia dissecta (Convolvulaceae): condiment, medicine, ornamental, and weed - a review. Economic Botany 61(2):109-120. <http:// dx.doi.org/10.1663/0013-0001(2007)61[109:MDCCMO]2.0.CO;2>

Bakasso S., Lamien-Meda A., Lamien C.E., Kiendrebeogo M., Millogo J., Ouedraogo A.G. \& Nacoulma O.G 2008. Polyphenol contents and antioxidant activities 
of five Indigofera species (Fabaceae) from Burkina Faso. Pak. J. Biol. Sci. 11(11):1429-1435. <http://dx.doi.org/10.3923/pjbs.2008.1429.1435> $<$ PMid:18817242>

Cook D., Beaulieu W.T., Mott I.W., Riet-Correa F., Gardner D.R., Grum D., Pfister J.A., Clay K. \& Marcolongo-Pereira C. 2013. Production of the alkaloid swainsonine by a fungal endosymbiont of the Ascomycete order Chaetothriales in the host Ipomoea carnea. J. Agric. Food Chem. 61(16):3797-3803. <http:// dx.doi.org/10.1021/jf4008423><PMid:23547913>

Dalto A.G.C., Bandarra P.M., Pedroso P.M.O., Guagnini F.S., Leal J.S., Raymundo D.L. \& Driemeier D. 2009. Timpanismo espumoso em bovinos leiteiros em pastagens de Trifolium sp. (Leg. Caesalpinoideae). Pesq. Vet. Bras. 29(5):401-403.<http://dx.doi.org/10.1590/S0100-736X2009000500007>

Dirksen G. 1993. Sistema digestivo, p.166-228. In: Dirksen G., Gründer H.D. \& Stöber M. (Eds), Rosenberger's Exame Clínico dos Bovinos. 3aㅡ ed. Guanabara Koogan, Rio de Janeiro. 419p.

Dirksen G., Gründer H.D., Stöber M. 1993. Rosenberger: exame clínico dos bovinos. $3^{\mathrm{a}}$ ed. Guanabara Koogan, Rio de Janeiro, 419p.

Embrapa 1997. Manual de Métodos de Análise de Solo. Centro Nacional de Pesquisa de Solo, Empresa Brasileira de Pesquisa Agropecuária, Rio de Janeiro. 212p.

Ferreira P.P.A. \& Miotto S.T.S. 2013. 0 gênero Merremia (Convolvulaceae) na Região Sul do Brasil. Rodriguésia, Rio de Janeiro, 64(3):635-646.

Forbes J.M. 1986. The Voluntary Intake of Farm Animals. ButterworthsHeinemann, London. 216p.

Gava A. 1990. Comunicação Pessoal. Departamento de Patologia, Centro de Ciências Agroveterinárias, UDESC, Lages, SC.

Ghosh A. \& Ghosh T. 2010. Herbal Drugs of Abuse. Sys. Rev. Pharm. 1(2):141145. <http://dx.doi.org/10.4103/0975-8453.75060>

Jenett-Siems K., Weigl R., Böhm A., Mann P., Tofern-Reblin B., Ott S.C., Ghomian A., Kaloga M., Siems K., Witte L., Hilker M., Müller F. \& Eich E. 2005. Chemotaxonomy of the pantropical genus Merremia (Convolvulaceae) based on the distribution of tropane alkaloids. Phytochemistry 66(12):1448-1464. <http://dx.doi.org/10.1016/j.phytochem.2005.04.027><PMid:15922373>

Kaneko J.J., Harvey J.W. \& Bruss M.C. 2008. Clinical Biochemistry of Domestic Animals. 6th ed. Academic Press, San Diego. 928p.

Kissmann K.G. \& Groth D. 1992. Plantas Infestantes e Nocivas. Vol.2. BASF, São Paulo, p.518-589.

Lima D.D.C.C., Albuquerque R.F., Rocha B.P., Barros M.E.G., Gardner D.R., Medeiros R.M.T., Riet-Correa F. \& Mendonça F.S. 2013. Doença de depósito lisossomal induzida pelo consumo de Ipomoea verbascoidea (Convolvulaceae) em caprinos no semiárido de Pernambuco. Pesq. Vet. Bras. 33(7):867-872. <http://dx.doi.org/10.1590/S0100-736X2013000700007>

Lorenzi H. 1982. Plantas Daninhas do Brasil: terrestres, aquáticas, parasitas, tóxicas e medicinais. Instituto Plantarum, Nova Odessa, SP, p.117-125.

Lorenzi H. \& Souza H.M. 1999. Plantas Ornamentais do Brasil: arbustivas, herbáceas e trepadeiras. 2nd ed. Instituto Plantarum, Nova Odessa, SP.

Mansur M. 2001. Merremia, p.366-373. In: Van Valkenburg J.LC.H. \& Bunyapraphatsara N. (Eds), Plant Resources in South-East Asia No.12: medicinal and poisonous plants. Vol.2. Prosea Foundation, Backhuys Publishers. Leiden, The Netherlands.

Meira M., Silva E.P., David J.M. \& David J.P. 2012. Review of the genus Ipomoea: traditional uses, chemistry and biological activities. Revta Bras. Farmacogn. 22(3):682-713. <http://dx.doi.org/10.1590/S0102-695X2012005000025>

Mello G.W.S., Oliveira D.M., Carvalho C.J.S., Pires L.V., Costa F.A.L., Riet-Correa F. \& Silva S.M.M. 2010. Plantas tóxicas para ruminantes e eqüídeos no
Norte Piauiense. Pesq. Vet. Bras. 30(1):1-9. <http://dx.doi.org/10.1590/ S0100-736X2010000100001>

Mendonça F.S., Evêncio-Neto J., Estevão L.R.M., Albuquerque R.F. \& Colodel E.M. 2011. Spontaneous poisoning by Ipomoea sericophylla (Convolvulaceae) in goats at semi-arid region of Pernambuco, Brazil: a case report. Acta Vet. Brno 80(2):235-239. <http://dx.doi.org/10.2754/avb201180020235>

Mendonça F.S., Albuquerque R.F., Evêncio-Neto J., Freitas S.H., Dória R.G.S., Boabaid F.M., Driemeier D., Gardner D.R., Riet-Correa F. \& Colodel E.M. 2012. Alpha-mannosidosis in goats caused by the swainsonine-containing plant Ipomoea verbascoidea. J. Vet. Diagn. Invest. 24(1):90-95. <http://dx.doi. org/10.1177/1040638711425948><PMid:22362938>

Nahrstedt A., Jensen P.S. \& Wray V. 1989. Prunasin-6'-malonate, a cyanogenic glucoside from Merremia dissecta. Phytochemistry 28(2):623-624. <http:// dx.doi.org/10.1016/0031-9422(89)80064-0>

O’Donell C.A. 1941. Revisión de las espécies americanas de Merremia. Lilloa 6:467-554.

Oliveira C.A., Riet-Correa F., Dutra M.D., Cerqueira D.V., Araújo C.V. \& Riet-Correa G. 2011. Sinais clínicos, lesões e alterações produtivas e reprodutivas em caprinos intoxicados por Ipomoea carnea subsp. fistulosa (Convolvulaceae) que deixaram de ingerir a planta. Pesq. Vet. Bras. 31(11):953-960. <http:// dx.doi.org/10.1590/S0100-736X2011001100003>

Oliveira C.A., Riet-Correa G. \& Riet-Correa F. 2013. Intoxicação por plantas que contêm swainsonina no Brasil. Ciência Rural 43(4):653-661. <http:// dx.doi.org/10.1590/S0103-84782013000400014>

Perez K.J.B., Jose M.A.I., Aranico E. \& Madamba M.R.S.B. 2015. Phytochemical and antibacterial properties of the ethanolic leaf extract of Merremia peltata (L.) Merr. and Rubus spp. Adv. Environ. Biol. 9(19):50-56.

Radostitis O., Gay C., Blood D. \& Hinchcliff K. 2002. Clínica Veterinária: um tratado de doenças dos bovinos, ovinos, suínos, caprinos e equinos, p.235304. 9a ed. Guanabara Koogan, Rio de Janeiro.

Riet Alvariza F. 1993. Intoxicación por nitratos y nitritos. In: Riet Correa F., Méndez M.C. \& Schild A.L. (Eds), Intoxicações por Plantas e Micotoxicoses em Animais Domésticos. Editorial Agropecuaria Hemisferio Sur, Montevideo, p.291-297.

Rissi D.R., Rech R.R., Fighera R.A., Cagnini D.Q., Kommers G.D. \& Barros C.S.L. 2005. Intoxicação espontânea por Baccharis coridifolia em bovinos. Pesq. Vet. Bras. 25(2):111-114. <http://dx.doi.org/10.1590/S0100736X2005000200008>

Silva D.M., Riet-Correa F., Medeiros R.M.T. \& Oliveira O.F. 2006. Plantas tóxicas para ruminantes e equídeos no Seridó Ocidental e Oriental do Rio Grande do Norte. Pesq. Vet. Bras. 26(4):223-236. <http://dx.doi.org/10.1590/ S0100-736X2006000400007>

Simão-Bianchini R., Vasconcelos L.V. \& Pastore M. 2016. Flora das cangas da Serra dos Carajás, Pará, Brasil: Convolvulaceae. Rdza. 67(5)1301-1318.

Tokarnia C.H., Döbereiner J. \& Peixoto P.V. 2000. Plantas Tóxicas do Brasil. Editora Helianthus, Rio de Janeiro. 310p.

Tokarnia C.H., Brito M.F., Barbosa J.D., Peixoto P.V. \& Döbereiner J. 2012. Plantas Tóxicas do Brasil para Animais de Produção. $2^{\underline{a}}$ ed. Helianthus, Rio de Janeiro. 223p.

Williams C.J. 2012. Medicinal Plants in Australia: plants, potions and poisons. Vol.3. Rosemberg Publishing, NSW, Australia, p.119-123.

Williams R.O. \& Williams R.O.J. 1969. The Useful and Ornamental Plants in Trinidad and Tobago Port of Spain. Government Printery. 